\title{
Analysis of Potential Non-Traditional Trading Partner Countries for Improving Indonesia's Trade Balance Through Countertrade Schemes
}

\author{
Choirin Nisaa' \\ Trade Analysis and Development Agency \\ Ministry of Trade \\ Jakarta, Indonesia \\ choirin.nisaa@gmail.com
}

\author{
Farida Rahmawati \\ Trade Analysis and Development Agency \\ Ministry of Trade \\ Jakarta, Indonesia \\ faridarahma13@gmail.com
}

\author{
Ayu Sinta Saputri \\ Trade Analysis and Development Agency \\ Ministry of Trade \\ Jakarta, Indonesia \\ ayu.sinta@kemendag.go.id
}

\begin{abstract}
Indonesia's trade performance in 2018 experienced a deficit of USD 3,8 Billion, due to increasing of oil and gas imports. Countertrade scheme is proven as one way to improve the trade balance for country who experienced trade balance deficit through increasing on oil and gas exports channel. This study aims to identify the non-traditional trading partners as well as the products that are potential to be selected as non-oil and gas export destination for Indonesia through countertrade scheme. This study utilizes trade performance index and the composite index analysis using different criteria when applied to select country and products. The results show that there are six potential countries include Saudi Arabia, Nigeria, Qatar, Angola, Azerbaijan and the United Arab Emirates. On the product side, Electronic and coal are the common potential products to be proposed through countertrade scheme as that products are potential in all selected countries. There are another eight potential products for six countries that are selected, include machinery, jewelry, cigarettes, dairy products, processed fruits, mollusks, vegetable materials, automotive, synthetic rubber, processed oily grains, processed fruits, coffee beans, CPO and its derivatives, pearls, processed fats $\&$ animal or vegetable oils, ash and metal scraps, precious metals, rice, salt, and sulfur and lime.
\end{abstract}

Keywords- Countertrade, Trade performance index, composite index

\section{INTRODUCTION}

Indonesia's trade balance during 2018 (JanuarySeptember) recorded a deficit of USD 3.8 billion. This trade balance experienced a pressure compared to the same period in 2017 which reached a surplus of USD 10.9 billion. The deficit in 2018 was triggered by an increase in the oil and gas trade deficit of USD 5.9 billion in January-September 2017 to USD 9.4 billion in January-September 2018. In addition, the non-oil and gas trade surplus decreased from USD 16, 7 billion in 2017 became USD 5.6 billion in JanuarySeptember. One of the causes of the increase in the oil and gas deficit was the increase in imports of oil products which resulted in a deficit of USD 11.67 billion, up from the previous year which reached USD 9.22 billion. On the other hand, oil product exports decreased by $7.0 \%$ YoY to USD 1.67 billion. Indonesia's oil and gas production in 2018 has decreased, one of which is the Mahakam block. Meanwhile the increase in oil and gas imports was influenced by rising economic activity.

Therefore, efforts are needed to increase non-oil and gas exports. One of them is by implementing a countertrade scheme, especially with trading partners which causes a deficit in the trade balance. The ten largest countries that contribute to Indonesia's total trade deficit during JanuarySeptember 2018 are China, Singapore, Thailand, Saudi Arabia, Australia, Nigeria, Germany, Qatar, Argentina and Canada.

Countertrade are bilateral agreements, usually between industrial companies in the West and state bodies or State Own Enterprises (SEOs) in developing countries where exports from industrial companies in the West are contractually connected with the trade in exports of other goods or services from counterparty trade partners (Caves and Marlin, 1991). Ellingsen (1991) defines trade returns more simply as transactions involving at least two-way transfer of goods, rather than transactions in goods and money.

Countertrade scheme has advantages, namely: (1) saving on the State Budget and Expenditure (APBN) and / or foreign exchange in order to purchase / import goods or services needed by government; (2) encourage the export and production of products included in the countertrade scheme; and (3) economic stimulus which has an impact on increasing employment between sectors (multiplier effects) ("Trade Balance, Deperindag Priority Program", 2003, pp. 3-7).

Therefore, in the context of the effectiveness of implementing trade-return schemes, especially to increase non-oil and gas exports to non-traditional countries and improve the trade balance, an analysis of identification of non-traditional trading partner countries has the potential to improve Indonesia's trade balance through countertrade schemes.

\section{RESEARCH MethodOLOGY}

The composite indicator is formed by combining various individual indicators into one indicator based on the specific model principal. The composite indicator is ideally capable of measuring multi-dimensional concepts that cannot be measured by individual indicators. However, the composite index in the area of policy, such as competitiveness, sustainable development, e-business readiness, etc. will be highly subjective, given that economic research in this field is still being developed (OECD,2008).

The International Trade Center (ITC) builds a trade performance index (Trade Performance Index or TPI) that aims to assess and monitor the dimensions of trade 
performance and multi-aspect competitiveness based on sectors and countries. TPI was built using a composite index based on the average performance of five indicators.

\section{A. Trade Performance Index for Countertrade Country}

This index is used to identify potential countries in countertrade schemes. Trade performance is measured using 3 indices, i.e.

1) Total trade balance performance index- Reflecting Indonesia's total trade balance value index with each trading partner country during the period JanuarySeptember 2018.

2) Performance index of oil and gas trade balanceReflecting the oil and gas trade balance index of Indonesia with each trading partner country during the period January-September 2018

3) Non-oil and gas export performance index- Reflecting Indonesia's non-oil and gas trade balance index with each trading partner country during the period JanuarySeptember 2018.

Data normalization is done for products whose trends are between the lowest value and the highest value. By using the Min-Max Normalisation method, the index is calculated using the following formula:

$$
I P_{j}=I_{t}-\frac{\left(N_{t}-N_{j}\right) x\left(I_{t}-I_{r}\right)}{N_{t}-N_{r}}
$$

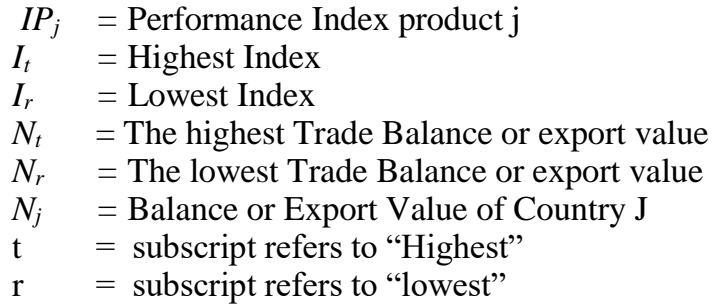

The chosen countertrade country is the one with the highest composite index. Composite index is the average of the four indices calculated using the formula:

$$
I_{k}=\underline{I P}_{n t} \underline{+I P} \underline{n m}_{n} \underline{+I P} \underline{e n m}
$$

$I_{k} \quad=$ Composite Index

$\underline{I P}_{n t}=$ Total trade balance performance index

$\underline{I P}_{n m}=$ Total oil and gas trade balance Index

$\underline{I P} \underline{e n m}_{\text {en }}=$ Non oil and gas performance Index

\section{B. Trade Performance Index for Countertrade Products}

The trade performance index is measured by a composite index with composition,

1) Indonesia Export Performance Index

Indonesia export performance index is measured using a composite index consisting of the growth trend index of exports to trading partner countries and the average export value index to trading partner countries

2) Trading country import demand performance index The performance index of import demand for trading partner countries is measured using a composite index consisting of import growth index of trading partner countries from the world and the index of average value of imports of trading partner countries from trading partner countries

3) Export market share performance index Shows growth index and average share of exports in trading partner countries over the past five years. This index is measured using a composite index consisting of the share trend index of Indonesian exports in the trading partner country markets and the average index of the share of Indonesian exports in the trading partner country markets.

4) Domestic supply performance index

Shows the growth index and the average value of Indonesian exports to the world over the past five years. The supply performance index is measured using a composite index consisting of Indonesia's export trend index to the world and the average value index of Indonesian exports to the world.

Data normalization is done for products whose trends are between the lowest value and the highest value by using the Min-Max Normalisation method as shown. The countertrade products chosen are those that have a highest composite index. The composite index is the average of the four indices which are calculated using a formula:

$$
I_{k}=\underline{I P} \underline{\underline{e}}+I P_{\underline{i}}+I P_{\underline{p}}+I P_{\underline{s}}
$$

$I_{k}=$ Composite Index

$\underline{I P}_{\underline{e}}=$ Export performance index

$\underline{I P}_{i}=$ Import performance Index

$\underline{I P_{p}}=$ Export market performance Index

$\underline{I P_{s}}=$ Domestic supply performance Index

\section{RESULT AND DISCUSSION}

\section{A. Identifying Potential Countries for Countertrade} Schemes

Identification of potential countries for countertrade schemes is carried out by considering the development of Indonesia oil and gas trade balance performance, Indonesia total trade balance performance, and Indonesia's non-oil export performance to trading partner countries. Countertrade notably encouraged to do with non-traditional trading partner which are Indonesia's oil and gas importers, considering the fact that oil and gas imports have caused a deficit in Indonesia's oil and gas trade balance. Furthermore, to increase the share of non-oil exports in non-traditional countries through countertrade, countries identification is also seen based on the performance of Indonesia's non-oil exports to non-traditional trading partner countries. Based on the calculation on composite index as seen in Table I, Saudi Arabia is the most potential country for countertrade schemes with the highest composite index score. During January - September 2018, Saudi Arabia supplies USD 2.6 billion in oil and gas to Indonesian market. Meanwhile, Indonesia non-oil and gas exports to Saudi Arabia in the same period amounted only USD 921.5 million. With countertrade agreement between Indonesia and Saudi Arabia, it is expected to encourage non-oil exports to Saudi Arabia 
TABLE I. POTENTIAL COUNTRY IDENTIFICATION RESULTS FOR JANUARY-SEPTEMBER 2018

\begin{tabular}{|c|l|r|r|r|r|}
\hline \multirow{2}{*}{ No } & Balance & $\begin{array}{c}|c| \\
\text { Index } \\
\text { Nos exports }\end{array}$ & $\begin{array}{c}\text { Oil and } \\
\text { Gas } \\
\text { balance }\end{array}$ & $\begin{array}{c}\text { Total } \\
\text { trade } \\
\text { balance }\end{array}$ & $\begin{array}{c}\text { Composite } \\
\text { Index }\end{array}$ \\
\hline 1 & SAUDI ARABIA & 94.07 & 59.84 & 47.01 & 70.9 \\
\hline 2 & NIGERIA & 97.41 & 48.45 & 40.98 & 66.5 \\
\hline 3 & QATAR & 98.63 & 39.75 & 38.52 & 63.0 \\
\hline 4 & AZERBAIJAN & 98.65 & 33.65 & 35.47 & 60.0 \\
\hline 5 & UAE & 93.10 & 39.23 & 35.14 & 59.9 \\
\hline 6 & Rep.of IRAN & 97.78 & 32.73 & 34.46 & 59.1 \\
\hline 7 & ALGERIA & 98.18 & 31.78 & 34.21 & 58.8 \\
\hline 8 & LIBYAN ARAB & 98.91 & 30.37 & 34.31 & 58.5 \\
\hline 9 & SUDAN & 98.66 & 30.31 & 34.27 & 58.4 \\
\hline 10 & CONGO & 98.96 & 29.88 & 34.18 & 58.3 \\
\hline 11 & GABON & 98.96 & 29.83 & 34.12 & 58.3 \\
\hline 12 & EQUATORIAL & 98.98 & 29.80 & 34.12 & 58.3 \\
\hline 13 & KUWAIT & 98.46 & 30.20 & 34.00 & 58.2 \\
\hline 14 & NORWAY & 98.77 & 29.29 & 34.13 & 58.0 \\
\hline
\end{tabular}

Besides Saudi Arabia, Nigeria following the rank by scored 66.5. This is due to the high oil and gas deficit from Nigeria with a value of USD 1.6 billion in JanuarySeptember 2018, resulting a total trade decficit of USD 1.4 billion. On the other hand, non-oil and gas exports to Nigeria were only USD 297.2.

Indonesia's non-oil and gas exports to Qatar, Angola and Azerbaijan during January-September 2018 were still low with a value of USD 69.4 million, USD 71.3 million and USD 66.0 million respectively. However, Indonesia's total trade performance with the three countries recorded a deficit caused by high oil and gas imports. Based on the performance of the Indonesia trade balance and exports of non-oil and gas, Qatar, Angola and Azerbaijan received high scores as potential countries for countertrade. These countertrade schemes with the three countries represent Indonesia's opportunity to seize the share of competing countries and increase the share of non-oil exports in the market.

Even though Indonesia's non-oil exports have been quite high in the United Arab Emirates market, which amounted to USD 1.1 billion during January-September 2018, the deficit in oil and gas trade with the country was also quite high and almost reached USD 1 billion. This caused Indonesia to still experience a total trade deficit with the United Arab Emirates. Therefore, based on the results of identification through the composite index, the United Arab Emirates is one of the potential countries for conducting trade cooperation.

\section{B. Identification of Potential Products for Trade Balance Schemes}

\section{a) Saudi Arabia}

Export product that has the biggest potential to be boosted is electronic. Saudi Arabia's electronic demand during 2013-2017 reached an average of USD 20.8 billion. Indonesia actually has electronic supply capabilities considering that during 2013-2017, the average value of Indonesia's electronic exports reached USD 11.0 billion. However, in that period, Indonesia only supplied electronics to Saudi Arabia worth USD 39.1 million. In addition to electronics, machines exports performance also has a high potential to be boosted.

Saudi Arabia demand for machine during 2013-2017 averaged USD 19,7 billion. During this period, Indonesia machinery export to Saudi Arabia only reached an average of USD 20.7 million, but the export trend grew positively by $7.4 \%$ per year. Saudi Arabia's jewelry market is also quite large, which is an average of USD 643.0 million during 2013-2017. Saudi Arabia's imports trends grew by an average of $14.2 \%$ per year. Thus, jewelry, including products that have the potential to be exported to Saudi Arabia, considering that Indonesia's exports to Saudi Arabia for jewelry are only averaging USD 164.6 thousand during 2013-2017 (Table II).

The countertrade scheme is also an opportunity for Indonesia to boost exports of primary industrial products. Based on the data, Saudi Arabia's imports of cigarettes, dairy products and processed food during 2013-2017 averaged USD 1.1 billion, USD 2.1 billion, USD 3.8 billion, and USD 5.4 billion. However, Indonesia's share in Saudi Arabia for these products is still lower than $1 \%$ (Table II).

The leading primary commodity which is also potential in the Saudi Arabian market is coal. Indonesia is one of the largest coals producing countries, but over the past five years has only supplied USD 210.4 thousand of coal to Saudi Arabia. Even though Saudi Arabia's coal demand for the past five years reached USD 42.8 million (Table II).

TABLE II. IDENTIFICATION OF COUNTERTRADE POTENTIAL MANUFACTURING PRODUCTS, PRIMARY INDUSTRY PRODUCTS, AND PRIMARY COMMODITY WITH SAUDI ARABIA

\begin{tabular}{|c|l|c|}
\hline \multicolumn{1}{|c|}{ Product } & Composite Index \\
\hline \multicolumn{3}{|c|}{ Manufacturing Products } \\
\hline 1 & Electronics & 67.0 \\
\hline 2 & Machinery & 59.1 \\
\hline 3 & Jewelry & 58.8 \\
\hline \multicolumn{3}{|c|}{ Primary Industry Product } \\
\hline 1 & Cigarrettes Commodity & 54.2 \\
\hline 2 & Dairy Product & 52.0 \\
\hline 3 & Processed fruits & 52.2 \\
\hline & \multicolumn{2}{|c|}{} \\
\hline 1 & Coal & 56.5 \\
\hline 2 & Mollusca & 51.5 \\
\hline 3 & Vegetable ingredients & 52.4 \\
\hline
\end{tabular}

For further information, Saudi Arabia isn't new to the term of counter trade. This country have done several agreement for example Saudi Arabia acquired ten Boeing 747 's which were paid for with a quantity of oil equal in valueto the full purchase price of the airplanes.

\section{b) Nigeria}

Potential manufacturing export products in Nigeria include automotive, electronics and machinery. Nigerian imports for automotive, electronics and machinery during 
2013-2017, which averaged USD 2.7 billion, USD 3.0 billion, and USD 5.2 billion. These products are also the main products of Indonesian exports to the world, so it can be concluded that Indonesia has the ability to supply Nigerian demand for these products. Nonetheless, the Nigerian market for these products has not been fully exploited by Indonesia. Thus, through a countertrade scheme, Indonesia is expected to capture the share of competitors in the Nigerian market (Table III).

TABLE III. IDENTIFICATION OF COUNTERTRADE POTENTIAL MANUFACTURING PRODUCTS, PRIMARY INDUSTRY PRODUCTS, AND PRIMARY COMMODITY WITH NIGERIA

\begin{tabular}{|c|l|c|}
\hline No & \multicolumn{1}{|c|}{ Product } & $\begin{array}{c}\text { Composite } \\
\text { Index }\end{array}$ \\
\hline \multicolumn{2}{|c|}{ Manufacturing Products } \\
\hline 1 & Automotive Primary Industry Product & 62.8 \\
\hline 2 & Electronic & 62.5 \\
\hline 3 & Machines & 62.1 \\
\hline \multicolumn{2}{|c|}{ Primary Commodity } \\
\hline 1 & Synthetic rubber & 56.3 \\
\hline 2 & Processed oily seeds & 54.3 \\
\hline 3 & Processed fruits & 71.0 \\
\hline \multicolumn{2}{|c|}{58.3} \\
\hline 1 & Coal & 57.0 \\
\hline 2 & Vegetable ingredients
\end{tabular}

Based on the results of composite index calculation, the potential primary industrial export product in Nigeria is synthetic rubber. Nigeria's demand for these products for the past five years has averaged USD 7.0 million. Meanwhile, Indonesia is able to export synthetic rubber to the world at USD 157.0 million. Indonesia export of synthetic rubber to Nigeria is still very low (Table III)

Potential export commodities in the Nigerian market include: coal, vegetable ingredients, and coffee beans. The primary commodity market in Nigeria is still wide open as seen from the trend of Nigerian trends for primary commodities from the world during 2013-2017 (Table III).

Nigeria ever experience counter trade with several countries. In 1983, Nigeria arranged a counter trade with Brazil worth USD 4 billion involved oil imports by Brazil in exchange for exports of soya, steel, cement, textiles, food products, and manufactured goods.

\section{c) Qatar}

Electronics and machines are one of the potential manufacturing products on the market (Table IV). During 2013-2016, the average export of Indonesia was 8.3 million and USD 5.2 million. In fact, in that period, Qatar's demand for electronics and machinery grew by 5.6\% and $9.4 \%$ respectively. In addition, Qatar's average demand for electronics and machinery in the same period reached USD 4.0 billion and USD 4.3 billion. Qatar's imports of primary industrial products also continued to grow positively and the import rate was quite large during 2013-2016. So far, Indonesia has not yet utilized the market for Qatar's primary industrial products to the fullest. Potential primary industrial products in Qatar include dairy products, cigarettes, and processed rubber. The Qatar market is quite large for coal, pearls, mollusks, cereals, vegetable materials, ornamental plants and cut flowers, salt, sulfur, and lime, fish, and fruits. Qatar imports trend for these commodities during 2013-2016 also recorded a significant growth. However, Indonesia has not captured this opportunity.

Earlier in 1983, together with Nigeria, Qatar arranged a counter trade with Brazil worth USD 2.3 billion involved oil imports by Brazil in exchange for exports of soya, steel, cement, textiles, food products, and manufactured goods.

TABLE IV. IDENTIFICATION OF COUNTERTRADE POTENTIAL MANUFACTURING PRODUCTS, PRIMARY INDUSTRY PRODUCTS, AND PRIMARY COMMODITY WITH QATAR

\begin{tabular}{|c|l|l|}
\hline No & \multicolumn{1}{|c|}{ Product } & Composite Index \\
\hline \multicolumn{3}{|c|}{ Manufacturing Products } \\
\hline 1 & Electronics & 67.3 \\
\hline 2 & Machines & 61.9 \\
\hline 3 & Jewelry & 59.9 \\
\hline \multicolumn{3}{|c|}{ Primary Industry Product } \\
\hline 1 & Cpo \& derivatives & 61.5 \\
\hline 2 & Dairy product (milk, butter, egg) & 54.9 \\
\hline 3 & Cigarettes (cigarrettes) & 53.5 \\
\hline \multicolumn{2}{|c|}{ Primary Commodity } \\
\hline 1 & Coal & 61.5 \\
\hline 2 & Pearl & 60.9 \\
\hline 3 & Mollusk & 55.7 \\
\hline
\end{tabular}

\section{d) Azerbaijan}

The average share of Indonesian exports to Azerbaijan during 2013-2017 was 0.4\%. Thus, Indonesia can still increase its exports and market share on this country. Most of Azerbaijan's imports of manufactured products during 2013-2017 continued to grow positively. The countertrade scheme can be an opening door for exports of manufacturing products such as jewelry, automotive, and chemical products

Meanwhile, potential primary industrial products in the Azerbaijan market include synthetic rubber, processed fruits, processed fats \& animal / vegetable oils, rice, processed foods, cigarettes, base metals, mineral fuel products, processed rubber, and processed coffee . The results of the identification of potential products are mainly seen based on the demand of Azerbaijan for these products which are quite large and still growing and Indonesia supply capacity to exports. Meanwhile, Indonesia has not use the Azerbaijan market for these products to the fulles. The same identification resulted several potential primary exports commodities to Azerbaijan through a countertrade scheme. The primary commodities include: coal, ash and metal scraps, and vegetable ingredients.

TABLE V. IDENTIFICATION OF COUNTERTRADE Potential MANUFACTURING PRODUCTS, PRIMARY INDUSTRY PRODUCTS, AND PRIMARY COMMODITY WITH AJERBAIJAN

\begin{tabular}{|c|l|c|}
\hline No & \multicolumn{1}{|c|}{ Product } & $\begin{array}{c}\text { Composite } \\
\text { Index }\end{array}$ \\
\hline \multicolumn{2}{|c|}{ Manufacturing Products } \\
\hline 1 & Jewelry & 60.6 \\
\hline 2 & Automotive & 58.8 \\
\hline 3 & Electronic & 58.4 \\
\hline \multicolumn{2}{|c|}{ Primary Industry Product } \\
\hline 1 & Synthetic rubber & 56.6 \\
\hline 2 & Processed fruits & 54.9 \\
\hline 3 & Processed fats \& animal / vegetable oils & 54.2 \\
\hline
\end{tabular}




\begin{tabular}{|l|l|c|}
\hline \multicolumn{2}{|c|}{ Primary Commodity } \\
\hline 1 & Coal & 61.2 \\
\hline 2 & Ash and metal waste & 56.2 \\
\hline 3 & Vegetable ingredients & 54.9 \\
\hline
\end{tabular}

e) United Arab Emirates

Three potential Indonesian manufactured products in the United Arab Emirates include: electronics, machinery, and automotive. Demand for the United Arab Emirates for these products from the world during 20132017 averaged USD 40.7 billion, USD 21.0 billion, and USD 20.5 billion, billion respectively, but the share of Indonesia's exports just reached $0.4 \%, 0.2 \%, 1.0 \%$, respectively. In fact, Indonesia should be able to export these products with a higher value considering that these products are the main products of Indonesia's exports. Furthermore, other manufacturing products that are also potential are seen based on demand from the United Arab Emirates and Indonesia's supply capabilities.

The United Arab Emirates also imports a lot of primary industrial products. One of the most imported is precious metals with an average value reached USD 33.0 billion. But so far Indonesia has only exported an average of USD 28.3 million, with a share of $0.3 \%$ in the United Arab Emirates market. With the countertrade scheme, Indonesia's precious metal exports to the United Arab Emirates are expected to increase because Indonesia is currently able to export an average of USD 2.4 billion in precious metals to the world.

Meanwhile, one of the potential primary commodities in the United Arab Emirates market is coal. During 2013-2017, the United Arab Emirates needed imported coal with an average value of USD 240.1 million. Meanwhile, the share of Indonesian coal recorded an average of $4.3 \%$. Even though Indonesia's coal exports to the world during this period averaged USD 9.3 billion. Indonesian coffee beans on the United Arab Emirates market during 2013-2017 also controlled a share of around $4.1 \%$ of the total demand of the United Arab Emirates which reached USD 30.1 million.

TABLE VI. IDENTIFICATION OF COUNTERTRADE POTENTIAL MANUFACTURING PRODUCTS, PRIMARY INDUSTRY PRODUCTS, AND PRIMARY COMMODITY WITH UNITED ARAB EMIRATES

\begin{tabular}{|c|l|c|}
\hline No & \multicolumn{1}{|c|}{ Product } & Composite Index \\
\hline \multicolumn{2}{|c|}{ Manufacturing Products } \\
\hline 1 & Electronic & 67.8 \\
\hline 2 & Machines & 60.3 \\
\hline 3 & Automotive & 59.2 \\
\hline \multicolumn{2}{|c|}{ Primary Industry Product } \\
\hline 1 & Precious metal & 64.7 \\
\hline 2 & Rice Commodity \\
\hline 3 & Synthetic rubber & 58.6 \\
\hline \multicolumn{2}{|c|}{58.4} \\
\hline 1 & Coal & 64.3 \\
\hline 2 & Salt, sulfur and lime & 58.6 \\
\hline 3 & Fruits & 57.0 \\
\hline
\end{tabular}

\section{CONCLUSION AND RECOMMENDATION}

Indonesia is recommended to run a countertrade schemes with non-traditional countries that recorded a large deficit of oil and gas trade. Countertrade are not only beneficial for improving Indonesia's trade balance, but also can open market access and boost non-oil exports in non-traditional countries. Non-traditional countries that have the potential to become partners in the Indonesian counter trade scheme include: Saudi Arabia, Nigeria, Qatar, Angola, Azerbaijan, United Arab Emirates, Iran, Algeria, Libya, Sudan, Rep. Dem. Congo, Gabon, Equatorial Guinea, Kuwait, and Norway.

Potential products for countertrade schemes with Saudi Arabia are manufacturing products: electronics, machinery, and jewelry. Primary industrial products: cigarettes (cigarettes), dairy products (milk, butter, eggs), and processed fruits. Primary commodities: coal, mollusks, and vegetable ingredients.

Potential products for countertrade with Nigeria, namely manufacturing products: automotive, electronics, and machinery. Primary industrial products: synthetic rubber, and processed oily grains. Primary commodities: coal, vegetable ingredients, and coffee beans.

Potential products for countertrade schemes with Qatar are manufacturing products: electronics, machinery, and jewelry. Primary industrial products: CPO \& derivatives, dairy products (milk, butter, eggs), and cigarettes (cigarettes). Primary commodities: coal, pearls, and molluscs.

Potential products for countertrade schemes with the United Arab Emirates include Manufacturing products: electronics, machinery, and automotive. Primary industrial products: precious metals, rice, and synthetic rubber. Primary commodities: coal, salt, sulfur and limestone, and fruits.

\section{ACKNOWLEDGMENT}

This research was supported by Trade Analysis and Development Agency, Ministry of Trade of Republic of Indonesia. Special thank to our colleagues from Center for Foreign Trade, Aditya Alhayat, Ayu Wulandani, Nova Aulia Bella, and Arinda Nur Latifah who provided insight and expertise that greatly assisted carry out the research.

\section{REFERENCES}

[1] Caves, R.E. and Marin, D., (1991). "Countertrade transactions: rationales, structure, outcomes". Harvard University

[2] Departemen Perindustrian dan Perdagangan. (2003). "Imbal Dagang Membangun Ekuitas Pasar Modal. Media Industri dan Perdagangan"

[3] Ellingsen, Tore. (1991). A model of Countertrade. Discussion Paper No. March 1991

[4] Marlin, Dalia dan Monika Schintzer. (2002). The Economic Institution of International Barter. The Economic Journal,Vol. 112, No. 479 (April 2002), pp. 293-316

[5] Mirus, Rolf dan Bernard Yeung. (1985). Economic Incentives for CountertradeDipresentasikan di dalam Administrative Sciences Association of Canada. Montreal Conference

[6] OECD. (2008). Handbook on Constructing Composite Indicators: Methodology and User Guide. OECD Publications 